\title{
RE-PRESENTING SELF: READING SOME VAN KALKER STUDIO PHOTOGRAPHS
}

\author{
Nkiruka J. Nwafor
}

\begin{abstract}
The photographic implement, from the earliest days of its invention in Europe, in 1839, has been used to document events considered as real. However, notions of 'reality' could be ambiguous as objects or sceneries intended to be photographed are sometimes constructed to represent an imagined stereotypical reality. In South Africa, as well as in other parts of Africa, earliest documented photographs of indigenous peoples, by many Europeans, usually depicted cultures that were ancient and, in their opinion, needed to be studied. Photography however, was subsequently used by the apartheid government in South Africa to control movement of blacks through identity (passport) photographs that classified people based on race. It eroded the dignity of blacks by presenting them in public media as being inferior, poor and violent. Nonetheless, photography has equally been appropriated by the people to project their dignity in contrast to the images widely represented. These photographs of how the indigenes saw themselves were often kept in private collections, such as family albums. This essay attempts to look at how photography was employed by the Van Kalker Photo Studio in Cape Town to depict the Blacks and 'Coloured' peoples in South Africa as responsible and enlightened people whose image of self representation deconstructs that upheld by the apartheid state.
\end{abstract}

\section{Introduction}

The Van Kalker Studio was started in Cape Town, South Africa by Mr. J. G. Van Kalker, a Dutch immigrant in 1937. He trained as a photographer in Europe ${ }^{1}$ probably before migrating to South Africa. The studio was located in the Cape Town community of Woodstock, precisely at 47 Victoria Road $^{2}$, in the Western Cape region of South Africa. It is in close proximity with such areas like the District Six, Table Mountain, Cape Nature, Table Bay, and the Cape Flats, V and A Waterfront and Robben Island, all in the Western Cape province in South Africa. Van Kalker photo studio was quite popular, while it existed under the management of its founder, due to its accessibility 
to major transport routes in the surrounding communities in Cape Town, as well as the cheap but also high quality prints that it offered. $^{3}$

Van Kalker was able to capture the diverse cultures that characterized South Africa's Cape Town community in the portrait photographs of his customers. Relatively not much information was gathered about Van Kalker's personal life and possible influences, except that those living within the Cape Town areas were quite attracted to his "very high quality work" and a Van Kalker portrait photograph was highly valued. ${ }^{4}$ Considering the constraint of time, it was not possible to interview people who had taken pictures at Van Kalker's studio before the studio became moribund. However I visited the District Six museum in Cape Town where I met the keeper of the Van Kalker photo collections. From there I gathered that Irwin Clemens, who bought over the studio after Van Kalker's death, donated about 200,000 negatives of Van Kalker's studio portrait photographs to the District Six Museum ${ }^{5}$ where it is currently being preserved.

It is from these District Six Museum collections that I selected seven 1955 photographs of South Africans 'Coloureds' and Blacks. I only used the 1955 collections housed by the museum since they were among the very few that had been digitalized. The rest are still in the traditional archival format. These would be analyzed to determine how Van Kalker has been able to identify and capture "the essence of the subject's personality and sense of self." ${ }^{\prime 6}$ This would be used to refute the stereotypical /ethnographic portrayal reflected in late $19^{\text {th }}$ to $20^{\text {th }}$ century South African photographs of blacks, and the derogatory precincts accorded Black and "Coloured" ${ }^{7}$ South Africans in the Apartheid regime.

\section{The Ambivalence of Stereotypes}

The earliest photographic images of Blacks and 'Coloureds' in South Africa, from the nineteenth to the twentieth century were taken by voyagers, merchants and missionaries who came alongside imperialists into Southern Africa, just like in other parts of Africa where colonialism had its effects..$^{8}$ These people mostly Europeans, used the newly invented daguerreotype ${ }^{9}$ to capture images that did remind them of places and peoples they had come across in their 
voyages across various South African Ports. ${ }^{10}$ These photographs were basically meant for the Europeans who saw such pictures as forms of curiosities. The photographs, sometimes meant for commercial purposes, were usually constructed to conform to "what a customer (mostly European) is usually willing to buy." "The individual's actual personality and place within the society was downplayed and in its place is an allusion to exoticism.

Since 'exoticism' or 'primitivism' was deemed as the 'authentic' constituent of African culture/ tradition, as featured in such photographic portraitures captured or demanded by Europeans, other aspects contrary to this idealized concept were deemphasized. ${ }^{12}$ There was this tendency to remove any sign of European or other external influence from such photographs of Africans. It is important to note that the field of ethnography and anthropology evolved from these flawed notions of Africa as earlier photographs of Africans were documented as evidence of cultures that needed to be preserved. In a bid to preserve them, external influences were not captured. The costume of the photographed was sometimes manipulated in such a way as to construct an untamed and unchanged African setting. This fixed image of Africans still exists even till date as Europeans touring various parts of Africa, continue to imagine that an 'authentic' African should be pictured dressed in hides and skins or in fabrics attributed to Africa. Africans who dress in Western or other forms of dressing (by choice and as a result of contact with the outside world), are sometimes not conceived as real Africans by Europeans.

Although the missionaries brought Christianity into Africa, early photographs of missionaries amidst black converts usually expressed a clear hierarchy and supremacy relationship. ${ }^{13}$ The priests or nuns were presented as being saintly and the rescuers of the "unenlightened heathens." 14 The missionaries were portrayed in white and bright immaculate apparels, in photographs, while the Africans were presented as being dirty, dark, and impure and undergoing both physical and spiritual cleansing. ${ }^{15}$

These notions concerning non-Europeans in South Africa were formally justified with the racially codified scientific/evolution theory (Darwinian classification) ${ }^{16}$ which saw certain groups as being the immediate living ancestors of humans or within the earliest 
cradles of human evolution. Particularly, the inhabitants of the Kalahari area of Southern Africa named the 'Bushmen' or San, were documented and categorized as the "the hunting and gathering societies who needed to be placed on reserves to conserve their culture."17 Those dubbed Hottentots / khoi-khoi, or referred to as pastoralists, and the Bantu, regarded as mixed farmers (also in Southern Africa), were all seen as the bearers of an almost extinct way of life. ${ }^{18}$ These depictions underlined ethnographic and anthropological studies which as John Wright notes "produced different imagings of the people who, in an era of colonialism, industrialism, and scientific racism came to be given a distinct identity ... in the minds and mouths of Europeans." 19

Consequently, these 'scientific' or 'racial type' studies of nonEuropean South Africans, as elsewhere in Africa, formally established with the aid of the photographic apparatus, ${ }^{20}$ had a clear effect on the rendering of portrait photographs of non-European South Africans. Wright's suggestion as to why non-European South Africans were presented in this mode was that the British and settler interests were then aiming to ascertain political, economical and cultural domination over the South African indigenous inhabitants. ${ }^{21}$ Photography therefore, in the accompanying hands of late nineteenth century anthropology, ${ }^{22}$ became a tool for capturing such erroneous notions of Africans as primordial savages that needed to be preserved.

As Michael Stevenson notes, the photographs were not "made for a black audience" but basically "taken for 'scientific' purposes or as stereotypical views." ${ }^{23}$ The photographs presented a Europeanized interpretation of primitivism which had become the predetermined depiction of non-Europeans as stereotyped and depersonalized objects. Most pictures of Africans depicted portraits of ravenous barbarism and nudity sometimes suggestive of pornography, or "the creation of racially based sexual metaphors" 24 as though there were no other external influence as a result of colonialism. In some cases, the subjects being photographed would only concede in order to avoid accruing the wrath of the colonial power in place, under whose authority the ethnographers (accompanied by their camera) operated. Africans were most importantly depicted with no sense of dignified aesthetics. ${ }^{25}$ By dignified aesthetics I mean that, subjects were 
sometimes not photographed in apparels of their own choice or projected in their everyday appearance, but rather are compelled to dress specifically in attires (often considered as traditional) that conformed with the expectations of the European market. Yet, there were no efforts by the photographer (usually whites) to indicate the actual stance of the subjects, since at the time the photographs were taken the influence of western modernity were already being felt in Africa.

However, prior to the institutionalization of apartheid ${ }^{26}$ in South Africa (from the late $19^{\text {th }}$ century to the early twentieth century), it is crucial to note that, as Santu Mofokeng observes, many black South Africans had portrayed themselves in photographs, of their own freewill, in "enlightened" or modern apparels which they wore perhaps on a daily basis. ${ }^{27}$ Thus signifying that black South Africans did not perceive themselves as 'noble savages' but rather as cultured people with dignity who adapted to change when possible. By the late nineteenth century, there had been middle and working class Blacks who were enlightened and had progress in their various spheres of endeavor.

Mofokeng noted that his educational history of South Africa did not include these group of progressive Blacks (the notions of progress often based on Western paradigms of modernity) ${ }^{28}$ since they were considered as threats to the White dominated South African government. Mofokeng pointed out that these middle class Blacks as at that time participated in politics and had rejected and confronted the authority's racially prejudiced rule. ${ }^{29}$ And as such, European South Africans devised all possible means through which to ensure that the political and economic power permanently resided in the hands of minority Whites. Some of the late nineteenth and early twentieth century photographs of enlightened Black South Africans, were to be located in people's family albums which if unveiled will continue to address suppressed issues concerning the authentic stance of black precursors.

Photography also acquired a different purpose in the apartheid regime. The apartheid state constructively used photography as a medium of, as Allan Sekula suggests, discipline, control and repression. ${ }^{30}$ Here Sekula reiterates Michel Foucault's mechanism of panopticism following, Jeremy Bentham's idea of an architectural 
system of social discipline, "designed to allow an oppressive surveillance of those without power by those with power." ${ }^{\text {"31 }}$ The ideals of the apartheid regime which not only placed Whites as the superior, powerful and privileged group, ensured that movements of other races and groups (Blacks, 'Coloured,' etc.) within certain areas in South Africa like Cape Town were curtailed and controlled with photographic "documents of identity" "32 ( that categorized passport photographs based on race groups). This period heralded the establishment of pass laws by the South African authorities intended to control the immigration of non-white South Africans into areas deemed fit for solely Whites. These consequently impoverished and denied Black and 'Coloured' South Africans access to land ownership or economically attractive ventures.

Such inhumane treatments saw non-white South Africans loosing not only their ancestral lands which had been their main source of income, but also their self worth. This sense of denial of freedom consequently resulted in the subjugated groups being portrayed, in many photographs, as worthless and lacking a dignified or aestheticized sense of self. They were considered as less human and expected not to associate with the 'more advanced' white South Africans in the apartheid era. Black South Africans were ultimately relegated to homelands ${ }^{33}$ and since there were limited sources of livelihood owing to space, many were forced to work as migrant labourers in the cities under deplorable conditions. Public depiction of Blacks and 'Coloureds' in photographs became synonymous with poverty, violence and everything negative. On the contrary, the private or personalized portrait photographs (mostly preserved in family albums), became avenue through which the subjugated groups re-presented or reconstructed themselves in more dignifying ways.

The Van Kalker studio was started at a period in South Africa when the racial discrimination that characterized apartheid operations was gradually being institutionalized. This period also reflected the realities of life in a segregated country owing to race issues which had affected how people of various groups interacted and how they perceived themselves and others. Contrary to the notions of apartheid as group segregations, the Cape environment or community saw people of various race coexisting freely particularly 
in areas like District Six, formally named the Sixth Municipal District of Cape Town ${ }^{34}$, and Woodstock. These areas during the early stage of apartheid (before the forced removals) ${ }^{35}$ of the 1940s to 1960 s were somewhat multi-ethnic and the domicile of diverse race groups ('Coloureds,' Blacks, Whites and Indians).

Many of its inhabitants then were descendants of freed slaves imported from Africa (Dahomey, Angola, Guinea, Malagasy), and particularly from the Far East and Asia, (Ceylon [now Sri Lanka], India and Indonesia). ${ }^{36}$ In addition to this group were the indigenous Xhosa inhabitants ${ }^{37}$ as well as Jewish, British and Dutch European immigrants. ${ }^{38}$ It was home to various categories of people who found its communal nature a suitable channel for obtaining meager income that helped reduce poverty conditions of many working class citizens in South Africa. The vibrancy of the neigbourhood was friendly, unique and such that, as Aline Tibbit recalls, people of different races could often sit on their steps or stand on street corners talking happily. ${ }^{39}$

However, in 1966, the area was marked out as a White area under the Group Areas Act, and so the inhabitants' homes were demolished and they were relocated to the barren areas of Cape Flats. ${ }^{40}$ It would also be noted that the Woodstock community which fortunately was not demolished, still retained its multiracial complexion. ${ }^{41}$ As a result of this the Van Kalker Studio remained in its initial site in Woodstock till date. The people within these communities seemed to have rejected the idea of being placed in separate areas based on race. This sense of freedom characterized the area where the Van Kalker studio was located. One, therefore, would be surprised that Mr. Van Kalker could have found the area's vibrancy suitable for his photography studio and consequently, this may have resulted in the non-prejudiced access to his photo studio by various groups. As such Van Kalker portrait photographs seemed to have captured the multiracial and multicultural nature of the area. And even after the demolition of places like District Six, its former residents still came from far places where they had been relocated to, just to have their photographs taken in the Van Kalker photo studio.

It can be argued that these photographs of the various racial groups particularly of Blacks and 'Coloureds' were attempts at rejecting the separationist policy of the period. These photographs of 
contradictory perceptions of Black and 'Coloured' South Africans were a non-violent protest against the excesses of the South African government in the sense that they were mute but with strong and codified visual messages that refuted racial cataloging. But most importantly to this writing is the argument that Van Kalker was able to present Blacks and 'Coloureds' not as impoverished, suppressed, controlled and criminalized groups by the nature of their place within the apartheid era, or as 'noble savages' or 'anthropological specimens ${ }^{42}$, but as people with dignity and exquisite sense of self. Van Kalker's aestheticized portrayal of Blacks and 'Coloureds,' in the same light as their White counterparts, reflected personalities and individuals with values, self-esteem and varied interesting sense of style. The people he photographed had a choice as to what cloth they wished to appear in and how they wanted to present themselves either in traditional or modern apparels.

The portrait photographs were usually of very high quality and in black and white monochrome prints. This may have contributed to the popularity of Van Kalker portrait photographs as it found its way into the albums of many families around the Western Cape Province. Van Kalker usually arranged his studio with simple props. These props included drawn curtains that appear at both ends of the background, chairs, cross patterned carpet, table with flower vase, cakes and rays of light that reflects on the subjects photographed and in the background. Though it is difficult to determine whether the subjects were dressed up in the studio, ordinarily they seem quite comfortable in their clothes and may have owned the clothes they wore, because clothes worn in the different pictures do not look similar.

In the shadows of these dislocations, however, these Van Kalker's photographs taken in 1955, may compel us to rethink the conception of self as erroneously portrayed in the late nineteenth and up to the mid- twentieth century stereotypical ethnographic portraits of non-white South Africans. In other words, it may suggests that the people were challenged to see themselves in a different perception as against the racially codified anthropological studies of the imperialists. Following Mofokeng's words, these images will be viewed "in the terms determined by (viewing) the subjects themselves, for they have made them their own." 43 


\section{Some Van Kalker Photographs: A Brief Analysis}

In figure 1, the picture forms an interesting triangular shape which is also evident in some Van Kalker photographs. The work presents five "Coloured" ${ }^{44}$ South African children of

various ages and from perhaps the same parents. The eldest, a girl, stands at their back, carrying the youngest with one arm while the other arm is placed on the back of the girl that sits to the right of the older boy. This creates a triangular shape perfectly framed by the curved ends of the chair. The two girls who both sit beside their brother have similar pattern of white lace clothing with their hands clasped in front and their feet crossed. The bright colour of the girls' dresses (common with females), contrasts with the dark strong 'Coloured' outfits of the boys. The older boy looks stern or aggressive or perhaps was caught unawares by the camera while the youngest, also a boy, seems the most cheerful.

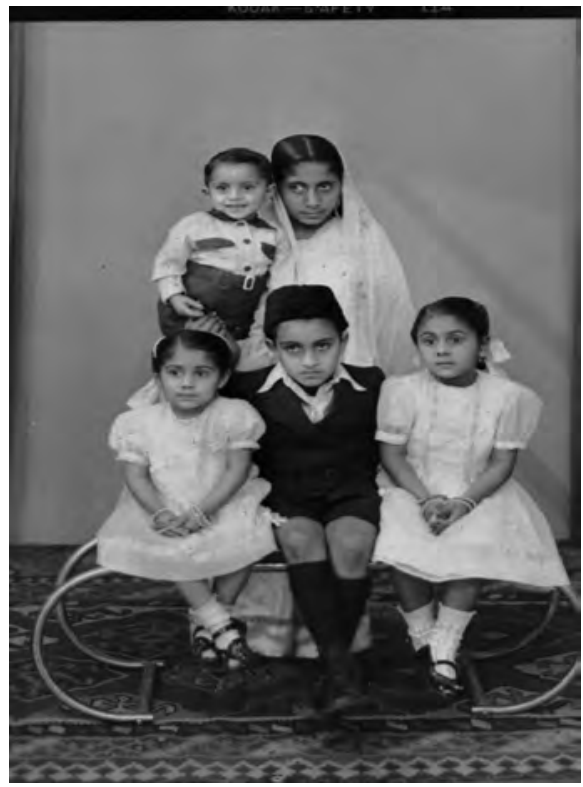

Fig. 1. Vk family, $2^{\text {nd }}$ July 1955. Collection of the District Six Museum, Cape Town, South Africa 
And generally their eyes are directed elsewhere to the left and not in contact with those of the photographer's. The oldest girl has a veil or hijab over part of her hair while her apparel seems to be much longer that those of the other little girls. Then the older sitted boy has a traditional Muslim cap on his head. This suggests that they might be perhaps children of the descendants of imported slaves from Far East Asia or Malagasy who came into the Cape along with their Muslim religion. ${ }^{45}$ Again, the Muslim culture probably dictates the age deemed proper for a girl-child to dress in a certain mode. This probably might explain the difference in the dress code of the older girl as against those of her younger siblings. They have been able to portray a mix of Muslim tradition with western apparels. The picture could also reflect how valuable children are in the lives of their parents and as such people keep photographic memories of their children in order to capture and recall their stages of development and achievements in life.

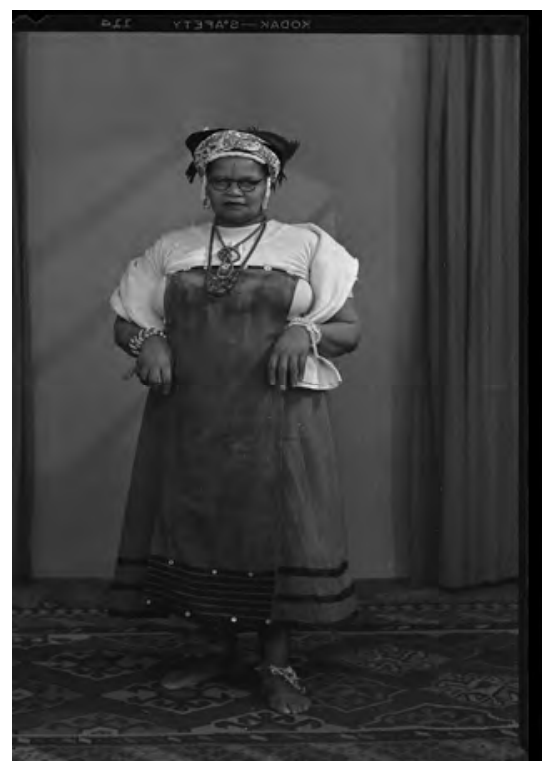

Fig. 2, May 1955 lady Collection of the District Six Museum, Cape Town, South Africa 
Figure 2 pictures a black South African lady dressed, as my informant ${ }^{46}$ noted, in an umbhaco (in Xhosa) traditional attire. It is made up of the skirt designed with bold dark stripes at the ends, and the top part covering the shirt, which is tied to the back of her shoulders. It is decorated with bright colourful beads or bold buttons, then over her shoulders is a blanket-like shawl which she holds in place with her arms. She also ties a beaded band or head tie across her hair and accessorized her bare feet with beads. The eye glasses and the surrounding props give the subject some sense of external or European influence. The information I gathered suggests that the person who dresses in this manner may be, endowed with spiritual powers or, a traditional healer (sangoma) undergoing certain rituals. ${ }^{47}$ Again it could be worn to symbolically commemorate circumcision or marriage ceremonies. The question of stereotyping may not come into play in this portraiture. This is because the subject looks confident and appears in control of her posture and comfortable with her choice of dressing. It does not look as though she was being stereotypical following the colonialist ethnographic ideal or manipulated to appear as such. This portrait could reflect that the story of the 'Western' dressed African and the story of the 'traditionally' dressed African is the same. They are all authentic Africans because it is not the apparel that makes one authentic. One may be forced to think that her dressing attempts to reiterate the European notion of Black Africans as being archaic. But on the contrary, I believe strongly that how one chooses to present oneself is a matter of choice or as a consequence of how he or she personally was able to interpret the immediate environment.

The young black gentleman in Figure 3 seems obviously out to make an impression. He has got on his hair a centre-parted afro hairstyle and this was perhaps what was in vogue in the 1950s since some notable black Africans, including South African politicians and intellectuals like Nelson Mandela have been spotted at some point in that hair style. His briefcase is well polished and the folded magazine recalls the graduation accessory suggesting that he may be aspiring towards being an intellectual. He has got a good sense of the western dressing code just like many Africans who were open to external influences. He probably could have an office job, or was 
dressed for a job interview or a scholar just out from the lecture room. These are all possibilities reflected in this photograph. The young man signifies the African man's quest to distinguish himself as an enlightened and dignified personality particularly in an era when being western or modern was (and still is) synonymous with success.

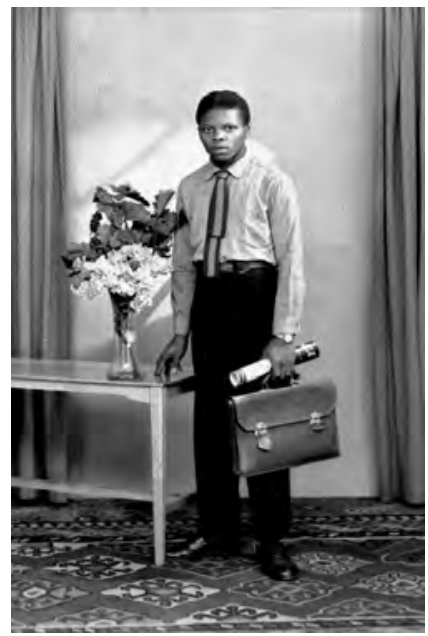

Fig 3, Van Kalker Men 2 November, 1955, Collection of the District Six Museum, Cape Town, South Africa

Figure 4 exhibits a simple but well-knit black South African family of six. Black South Africans families seem to have been the most affected by apartheid. Families had to be separated for months from their fathers who worked as migrant labourers and as such portrait photographs served as temporary succor against present realities. Van Kalker also formed a triangular shape with this family in the same way that he did the five children earlier mentioned. The father is dressed in a dark suit and well polished shoes, and is also seated and carrying the baby. The little boy clinging on the dad's laps appears in a slightly dark overall with matching cap. This seems to have created the impression of a dedicated father who is supposedly the head of the family. The standing position of the mum also seems to attest to the protective and caring role often ascribed to mothers within the family. It may also reflect how much value was attached 
to families by black South Africans then. The little boy behind the mum seems to be standing on something, perhaps, a small stool to have reached such height. They are dressed in western clothing while mum and daughter are spotted in gowns. The portrait could reveal a young and modest family's strive to give their children proper care and education although the repressive nature of racism (apartheid), which may have probably limited their source of income, does not necessarily encourage such. Their clothes appear neat and they seem to have dressed, perhaps for church or had specifically planned for an outing.

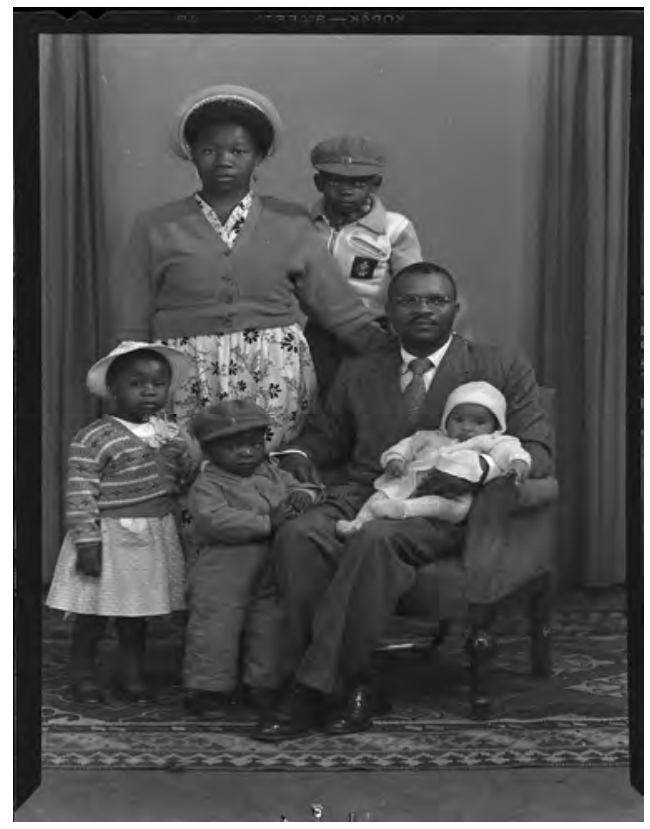

Fig4, Van Kalker family, October 1955, Collection of the District Six Museum, Cape Town, South Africa. 


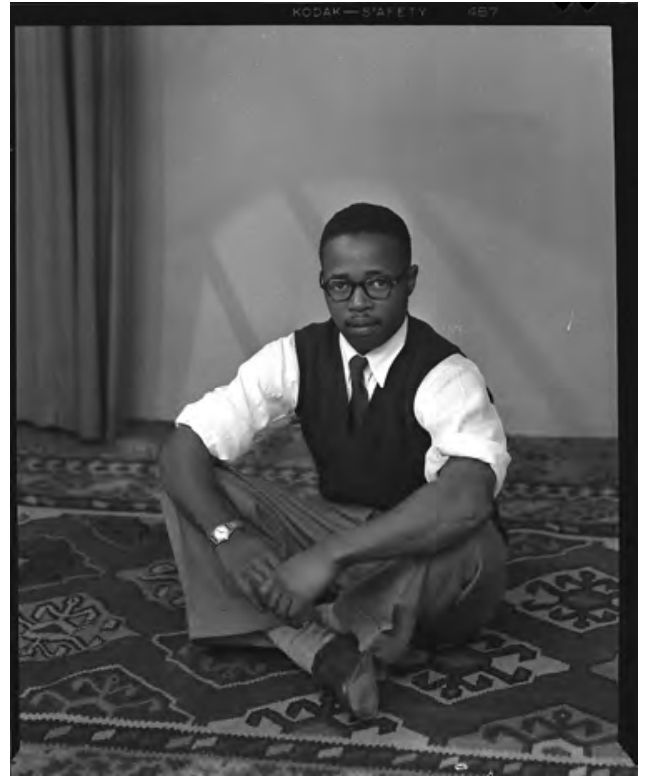

Figure 5, Van Kalker gents. January 1955, Collection of the District Six Museum, Cape Town, South Africa

In figure 5, the gentleman's pose seems casual and relaxed even though he is formally dressed in a sleeveless sweater, with added accessories such as wristwatch and eye glasses. The cross patterned design of the carpet, seems to have been particularly accentuated by his posture as well as the marks created by the rays of light in the background. Interestingly considering that the gentleman sit on the floor with both legs crossed, the rays of light still seems to fall on his face. Whereas in the photographs where the subjects either stand or sit on a chair, the positioning of the light seems to vary either reflected at their chest area or on their face. This may suggest that the light is not naturally reflected from the window, as I earlier thought, rather it could have been artificially created. The lighting effect also seems to add a subtle beauty to all Van Kalker's works.

The picture in fig. 6 is reflecting a lady with perhaps her two children. The little boy in dark trousers and white long sleeved shirt stands between the two females. The girl's gown seems made from 
some sort of satin and lace fabric and in addition hers and her mum's gown (both short-sleeved) are brightly coloured as against the dark tone of the boy's trousers. The mum wears a pearl-like necklace with earrings and also has a rosette attached to the top part of her cloth. The females' wavy hairstyles look quite similar except for the girl's additional hair band. The clothes do not seem to have been temporarily borrowed, they look quite comfortable in them and their confident poses give them an aura of elegance and definitely no sense of poverty. The handbags that mother and daughter are carrying have similar shapes and its dark tone seems to be highlighted by their gowns. Interestingly there appears to be no fatherly figure and one may wonder why it is so. Perhaps it signals how central Black women are in the day to day affairs of the family and particularly children. Mothers made necessary arrangements concerning birthday celebrations and other social occasions. They seem to have dressed for a special occasion, could have been a wedding, birthday party or any other ceremony which they chose to memorialize photographically in Van Kalker's studio.

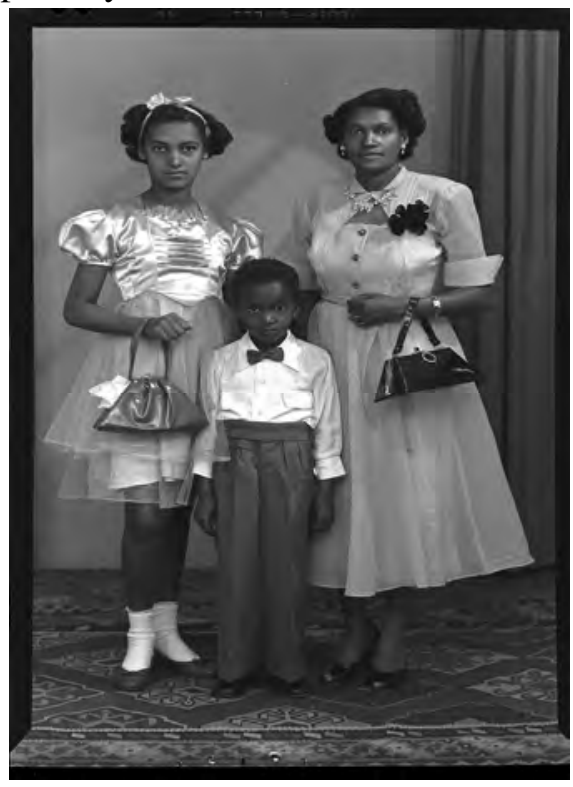

Figure 6, Van Kalker group, 16, 1955. Collection of the District Six Museum, Cape Town, South Africa 


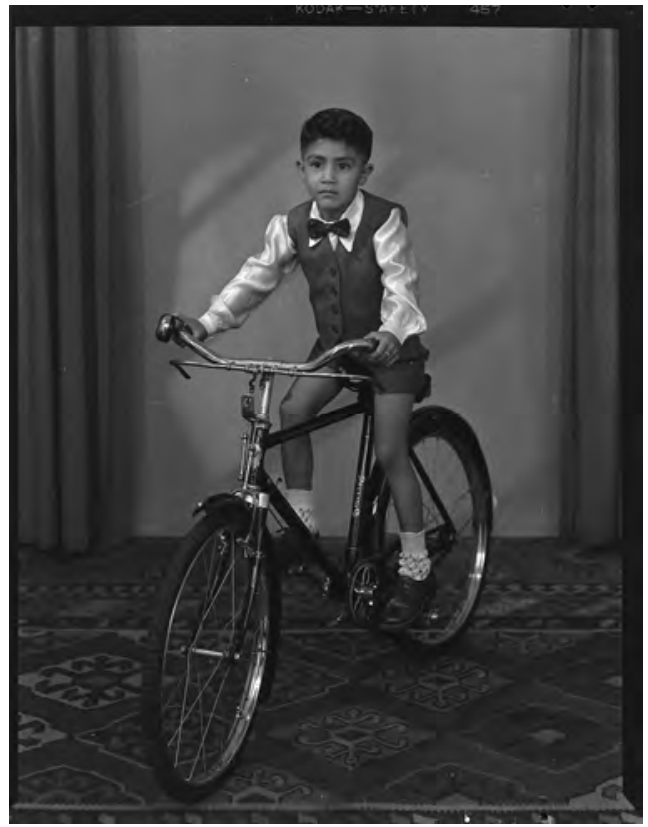

Figure 7: The 'Coloured' Boy Vk January-February 1955 23, Collection of the District Six Museum.

The 'Coloured' boy in figure 7 could be about eight or nine years old. The boy has a dark petticoat over a long sleeved white shirt and shorts. He sits astride a bicycle which is not intended for children within his age bracket since his legs could barely reach the bicycle pedals. The bicycle could be his father's or meant for an older sibling or friend. Van Kalker may have captured the subject's restrained unease. This could suggest that the adventurous boy appears not to care for his fear of falling off the bicycle since his main interest is getting a picture of himself on this bicycle or personalizing the object that he so much cherishes. Children of such age often do fantasize about their parent's priced properties which they too aspire to acquire in the future. One would not be surprised to see them acquiring various toys which are the closest they can get to owning properties at that stage. This they further try to reflect by emulating and seeing their parents as role models of what they 
would like to be in future. Parents on the other hand sometimes used such valuables which children are attached to, to entice and get their children to be obedient and loyal to them. Such promises as taking snapshots of a child on a bicycle could elicit such excitement. Van Kalker's fluidity could be observed here in the sense that he is willing to add personalized props in order to capture the subject's special moments. However, the bicycle could also be one of Van Kalker's props.

\section{Conclusion}

The 1955 Van Kalker photographs analyzed above therefore, has shown that the derogatory precincts accorded black and coloured South Africans in ethnographic photographs have been deconstructed. This is as a result of the interesting and creative ways in which the subjects have presented themselves in the photographs. The people featured in these photographs went to the Van kalker Studio on their own accord and chose to present themselves in this light. The subjects, as portrayed in Van Kalker photographs, have been able to construct their personalized perception of themselves as dignified beings against that forcibly ascribed to them in ethnographic/anthropological photographic studies and the effects of racial segregation(apartheid). 


\section{References}

${ }^{1}$ K. Blair cited in Natasha Becker, 'The lives of colour exhibition. South African National Gallery, September 1999', in Kronos, Special issue: Visual history, Journal of Cape History No. 27, November 2001.p.273. ${ }^{2}$ History of Van Kalker, Van Kalker Photo Studio, http://www.vankalker.com/index.php?option=com_content\&task=view\&id $=12 \&$ Itemid=26 visited on $15^{\text {th }}$ May, 2009.

${ }^{3}$ Natasha Becker, 'The lives of colour exhibition. South African National Gallery, September 1999', in Kronos, Special issue: Visual history, Journal of Cape History No. 27, November 2001.p.273.

${ }^{4}$ Ibid, p. 281.

${ }^{5}$ The District Six Museum, located within the Cape Town environ of South Africa, is a commemorative church building that houses artefacts and other documents symbolic of the District Six community in Cape Town that was demolished by the Apartheid government following the Group Areas Act. District Six was declared "White" under the Group Areas Act, on $11^{\text {th }}$ February 1966, leading to the forced removal of all non-whites (Blacks and "Coloureds") living in the area. And as such, all physical structures (except churches and mosques) were destroyed. See Charmaine McEachern, "Working with Memory: The District Six Museum in the New South Africa', in Social Analysis 42(2) July 1998, p.48.

${ }^{6}$ Natasha Becker, 'The lives of colour exhibition. South African National Gallery, September 1999', in Kronos, Special issue: visual history, Journal of Cape History No. 27, November 2001.p.273.

${ }^{7}$ The term "Coloured" was used, during the apartheid era, to refer to people of Asian descent who had either been brought as slaves, by the Dutch, to South Africa or had migrated of their own accord. The term also refers to South Africans who are products of interracial marriages and could no longer be placed within the categories of either Blacks or Whites. ${ }^{8}$ Jeremy Silvester, Patricia Hayes and Wolfram Hartmann, “"This ideal conquest": photography and colonialism in Namibian history', in (eds.) Silvester, Hayes and Hartmann, The colonial camera: Photographs in the making of Namibian History (University of Cape Town Press, South Africa, 1998), p.10.

${ }^{9}$ Daguerreotype was the name given to the first photographic technique invented by Louis Daguerre in 1839. Some of these merchants and missionaries came along with Daguerreotype camera to capture some of the interesting scenes in Africa. See. Ibid. 
${ }^{10}$ Michael Stevenson and Michael Graham-Stewart, 'Surviving the lens: Photographic studies of South and East African people, 1870-1920' (Fernwood press, UK\&Cape Town,) p.17.

${ }^{11}$ David Prochaska, 'Fantasia of the Phototheque: French postcard views of colonial Senegal' in African Arts : Historical photographs of Africa No. 4, Vol XXIV,University of Califonia, Los Angeles, October 1991, p.41.

${ }^{12}$ Michael Stevenson and Michael Graham-Stewart, p23.

${ }^{13}$ Christraud M. Geary, 'Missionary Photography: Private and Public Readings', in African Arts : Historical photographs of Africa No. 4, Vol XXIV,University of Califonia, Los Angeles, October 1991, p.49. ${ }^{14}$ Ibid.

${ }^{15}$ Ibid.

${ }^{16}$ Santu Mofokeng, 'The Black Photo Albulm/look at me: 1890-1900s', in NKA Journal of contemporary African Art Spring 1996, p.695.

${ }^{17}$ The Bushman or San refers to some indigenous groups that inhabited Southern Africa, particularly the Western Cape before the Dutch, British and other parts of Europe and Asia, migrated into Southern Africa. See Andrew B. Smith, 'The Kalahari Bushman Debate: Implications for Archaeology of Southern Africa' in South African historical Journal Vol. 35(November 1996), p.16.

${ }^{18}$ The Khoi Khoi and Bantu are also some of the earlier indigenous inhabitiants of Southern Africa that were displaced by the European immigrants into Southern Africa. See John Wright, 'Sonqua, Bosjesmans, Bushmen, abaThwa: Comments and queries on pre-modern identities' in South African Historical Journal Vol. 35(November 1996), p.18. ${ }^{19}$ Ibid.

${ }^{20}$ Andrew Bank, 'Anthropology and portrait photography: Gustave Fritsch's 'Natives of South Africa', 1863-1872', in KRONOS, Journal of Cape history, No.27 (UWC,November, 2001)p.43.

${ }^{21}$ Ibid.

${ }^{22}$ Christopher Pinney, 'The parallel histories of Anthropology and photography', in Elizabeth Edwards (ed.), Anthropology and Photography, (New Haven: Yale University Press, 1992), p.74.

${ }^{23}$ Michael Stevenson and Michael Graham-Stewart, 'Surviving the lens: Photographic studies of South and East African people, 1870-1920', (Fernwood press, UK\&Cape Town,) p.31.

${ }^{24}$ Andrew B. Smith, Sara Bartman and Khoisan Slavery, in South African historical Journal, No. 35,(November 1996), p.113.

${ }^{25}$ Michael Stevenson and Michael Graham-Stewart, ibid.p.18.

${ }^{26}$ Apartheid was formally instituted in the mid-1940s. 
${ }^{27}$ Santu Mofokeng, 'The Black Photo Albulm/look at me: 1890-1900s', in NKA Journal of contemporary African Art Spring 1996, p.70.

${ }^{28}$ Karel Schoeman, The face of the country: a South African family album, 1860-1910' (Human \& Rousseau, Cape Town, 1996), p.58.

${ }^{29}$ Santu Mofokeng, Ibid. p.71.

${ }^{30}$ Allen Sekula, 'The Body and the Archive', in (ed.) R. Bolton, The contest of meaning: Critical histories of photography (Massachussets, 1989), p.347.

${ }^{31}$ Allen Sekula, 'The Body and the Archive', in (ed.) R. Bolton, The contest of meaning: Critical histories of photography (Massachussets, 1989), p.21.

${ }^{32}$ Uma Dhupelia-Mestherie used this phrase as a sub-title in this article. See Uma Dhupelia-Mesthrie, 'The Form, the Permit and the photograph: An Archive of Mobility between South Africa and India' A paper presented to Conference on Print cultures, nationalisms and Publics of the Indian Ocean, Indian Ocean network, University of Witwatersrand, 15-17 January 2009. She shows how archived photographs of Indian slaves or immigrants into Africa used as documents for checking the influx of Indians into South Africa, by Imperialists in the nineteenth and twentieth century, have become valuable for some Indians South Africa in tracing their ancestral genealogies, in the post-apartheid era.

${ }^{33}$ Homelands are overcrowded area that the apartheid government designated to Black South Africans. The landmass was usually very small compared to the large population of blacks and often lacked necessary amenities and space for farming. The homelands were also constructed to recall "imagined" traditional African settings. It was in such areas that Blacks were expected to live in separate from Whites and Coloureds. ${ }^{34}$ The History of District Six Museum, http://thedistrict.co.za/districtsix.htm visited on 15th May, 2009.

${ }^{35}$ Forced removals is a popular phrase used to refer to the demolition carried by the Apartheid government in an effort to remove non-Whites from areas deemed to be solely meant for Whites. See Footnote on District Six museum above.

${ }^{36}$ Frank R. Bradlow, 'The origins of the early Cape Muslims', in (eds.), F. R. Bradlow and Margaret Cairns, The early Cape Muslims: A study of their mosques, genealogy and origins (A.A. Balkema, Cape Town, 1978), p.86. ${ }^{37}$ Ciraj Rassool, 'Community Museums, Memory Politics, and Social Transformation in South Africa: Histories, Possibilities, and Limits.', in (eds) Ivan Karp, Corinne A Kratz, Lynn Szwaja, and Tomas Ybarra- 
Frausto, with Gustavo Buntinx, Barbara Kirshenblatt-Gimblett and Ciraj Rassool, Museum Frictions: Public Cultures/Global Transformation (Duke University Press, Durham and London, 2006), p.286.

${ }^{38}$ Catherine Besteman, Transforming Cape Town, (University of Califonia Press, Califonia, 2008), pp.4-5.

${ }^{39}$ Dr. Aline Tibbit, 'A month in District Six in 1937' in (ed.) Anne Schuster, Piecing together the Past (District Six Museum, Cape Town, 2000), p.77.

${ }^{40}$ The History of District Six Museum, http://thedistrict.co.za/districtsix.htm visited on 15th May, 2009.

${ }^{41}$ Springerlink journal article, 'Inner city gentrification in South Africa: The case of Woodstock, Cape Town' Volume 30, Number 1, May, 1993, http://www.springerlink.com/content/mw756500v3258u26/

${ }^{42}$ Andrew B. Smith, 'The Kalahari Bushman Debate: Implications for Archaeology of Southern Africa' in South African historical Journal 35(November 1996), p.16.

${ }^{43}$ Santu Mofokeng, 'The Black Photo Album/look at me: 1890-1900s', in NKA Journal of contemporary African Art Spring 1996, p.69.

${ }^{44}$ The term "coloured" is used here to refer to South Africans who are neither whites nor blacks.

${ }^{45}$ Yusuf da Costa and Achmat Davids, Pages from Cape Muslim History (Shuter \& Shooter(pty) Ltd, Cape Town, 1994), p.8-15.

${ }^{46}$ Oral interview with Nolitha Ngcai, University of the Western Cape, $15^{\text {th }}$ Friday, 2009.

${ }^{47}$ Ibid. 